Vraj R. Shah, Jaydip D. Bhaliya and Gautam M. Patel*

\title{
In silico approach: docking study of oxindole derivatives against the main protease of COVID-19 and its comparison with existing therapeutic agents
}

https://doi.org/10.1515/jbcpp-2020-0262

Received August 16, 2020; accepted January 2, 2021;

published online February 17, 2021

\section{Abstract}

Objectives: Presently, the pandemic of COVID-19 has worsened the situation worldwide and received global attention. The United States of America have the highest numbers of a patient infected by this disease followed by Brazil, Russia, India and many other countries. Moreover, lots of research is going on to find out effective vaccines or medicine, but still, no potent vaccine or drug is discovered to cure COVID-19. As a consequence, many types of research have designated that computer-based studies, such as protein-ligand interactions, structural dynamics, and chembio modeling are the finest choice due to its low cost and time-saving features. Here, oxindole derivatives have been chosen for docking because of their immense pharmacological applications like antiviral, antidiabetic, anti-inflammatory, and so on. Molecular docking of 30 oxindole derivatives done on the crystallized structure of the protein (COVID-19 Mpro).

Methods: The process of docking, interaction, and binding the structure of ligand with protein has executed using Molegro Virtual Docker v.7.0.0 (MVD) and visualized the usage by Molegro Molecular Viewer v.7.0.0 (MMV).

Results: Among the 30 derivatives, the outcomes depicted better steric interaction and hydrogen bonding amongst OD-22 ligand, OD-16 ligand, OD-4 ligand, and OD-9 ligand (oxindole derivatives) with COVID-19. In addition to this, the comparative study of these four compounds with existing drugs that are under clinical trials shows comparatively good results in terms of its MolDock scores, H-bonding and steric interactions.

\footnotetext{
*Corresponding author: Gautam M. Patel, Department of Chemistry, School of Science, ITM SLS Baroda University, Vadodara, India, E-mail: gautampatel1573@yahoo.co.in

Vraj R. Shah and Jaydip D. Bhaliya, Department of Chemistry, School of Science, ITM SLS Baroda University, Vadodara, India. https://orcid.org/0000-0002-8834-5809 (J.D. Bhaliya)
}

Conclusions: Hence, It is proposed that these four oxindole derivatives have good potential as a new drug against coronavirus as possible therapeutic agents.

Keywords: COVID-19 Mpro; existing drugs; molecular docking; Molegro Virtual Docker; oxindole derivatives.

\section{Introduction}

The outbreak of COVID-19 recognized as severe acute respiratory syndrome coronavirus 2 arises from Wuhan, Hunan seafood wholesale market, China. The genome of the SARS-CoV-2 is similar to the bat genome which is in a proportion of $96 \%$ similarity [1]. In Guangdong City of China confirmed the first case of coronavirus through the local transmission [2]. On 4th March 2020, an international health emergency declared by the WHO (World Health Organization), in this year on 11th August 2020, a total of 19,936,210 verified cases worldwide, with 732,499 deaths data received by WHO. COVID-19 cases are still surging due to their quick transmission [3]. The virus is made by two layers in which one is an outer layer known as protein crown and another one is the inner layer that is the core of the virus called genetic material [4]. The symptoms of this virus vary from the severe cold to lots greater extreme ailments like SARS and MERS [5]. Furthermore, to prevent the pandemic of coronavirus, until today there is no targeted vaccine or drug available (except Favipiravir, this is a drug used to treat mild symptoms of infected patients, which recently launched by Glenmark). Indeed, there is an urgent need to identify and develop effective medicine against COVID-19 to fight this deadly virus [6]. In silico based study is one of the most important and advanced for the invention of a new drug. To eliminate the high cost of clinical trials and heavy time consumption several bioinformatics methods are nowadays used. The Virtual screening of various compounds on the protein-related study is the most obligatory bioinformatics technique used for the implementation of new medicines design [7]. 
Since heterocyclic compounds are well known for its medicinal activities [8]. Among them, one of the significant choices is oxindole, in which the benzene ring is incorporated with a pyrrole ring, and on the second position carbonyl group is present, The IUPAC name of the oxindole nucleus is 1,3-dihydro-2H-indole-2-one. To add with this, oxindole derivatives represent plethora medicinal activities, various pharmacology reports show that the modified oxindole derivatives encompass different activities, for instance, antiviral, anticancer, antimicrobial, antiinflammatory, analgesic, antioxidant, and antidiabetic activities due to these activities it attracts researchers for working on this compound [9]. Moreover, the synthesis procedure of oxindole derivatives is Eco-friendly as well as affordable, there is a surplus of green routes available to synthesis such compounds. Some merits that can be highlighted which varies from high yields to safe, cheap, and simple workup procedures [10]. Henceforth, 30 oxindole derivatives have been chosen for molecular docking through Molegro Virtual Docker version 7.0.0 Software (MVD). In this particular, these compounds run over a COVID-19 main protease (Mpro) which is a possible drug target macromolecule for the inhibition of COVID-19 replication. The protein which has been selected (PDB ID: 6LU7) is a key macromolecule for the chemical action of the drug molecule. Among all 30 oxindole derivatives, four oxindole derivatives exhibit moderate to excellent results via simulation. In addition to that comparative study with existing drugs has also been incorporated.

\section{Materials and methods}

\section{Protein preparation}

Three-dimensional protein structure of COVID-19 obtained from protein data bank (PDB ID: 6LU7) which can be directly opened at the URL (http://www.rscb.org/pdb), under the criteria of resolution $2.16 \AA$ [11]. Generally, most of the crystallized protein structures instead of the COVID-19 consist more than one chain but, in the case of COVID-19 protein includes only one chain that is (A). Moreover, the obtained structure also combined with water molecules and co-factors. Once the PDB's imported into the MVD (Molegro Virtual Docker version 7.0. 0 software) manual procedure was done to remove water molecules and co-factors. Furthermore, to execution the absent charges, protonation states, and allocating of polar hydrogen the special molegro algorithm was used.

\section{Ligand preparation}

SDF format ( ${ }^{\star}$ sdf) had been chosen to save 3D structures of oxindole derivatives and drugs under clinical trials (obtained through pubchem), the conversion of $2 \mathrm{D}$ to $3 \mathrm{D}$ structures was done by
Chembiodraw v. Ultra 12.0 software followed by energy minimization by using MM2 force field method in the same software, these procedures are essential before ligands import for docking process. 2D and 3D structures of all ligands are shown in Table 1. To get perfect results of docking study, it is significant that the imported structures must be well prepared like the atom connectivity and bond orders are right if, ligand file saved in PDB format usually have the bad or lacking undertaking of express hydrogens, and the PDB file structure would not adapt bond order information. Addition of $\mathrm{H}$-atom and all essential valency checks done by the implemented algorithm in the MVD.

\section{Cavity (or active sites) detection and selection}

The Cavity detection algorithm is an inbuilt function of MVD v.7.0.0 software, which automatically detects the possible binding sites (cavities) the cavities found inside $30 \times 30 \times 30 \AA^{3}$ cube, which uses for ligand binding. After cavities are recognized through the cavity detection algorithm, in this process the algorithm focus on pursuit the specific area or volume during the simulation process. Here, the program detected four different binding sites of COVID-19 protein structure (Figure 1). From these four anticipated cavities the one with the utmost volume (131.072 $\left.\AA^{3}\right)$, surface area $\left(417.28 \AA^{2}\right)$ and coordinates values of highest volume $(X=-10.6241, Y=15.4211$, and $Z=68.2623)$. Hence, this particular cavity had been considered for the ligandbinding process.

\section{Molecular docking studies}

After importing the main protease of COVID-19 in the MVD program [12], the 30 oxindole derivatives and four existing drugs had been docked against the COVID-19 crystal structure. During the docking process GRID resolution was set to $0.30 \AA$, and the center of active sites was set on the Coordinates values $\mathrm{X}=-10.6241, \mathrm{Y}=15.4211$, and $Z=68.2623$. Default parameters were used which consists of a maximum iteration of 1,500 and the highest population size of 50 . After that, 10 independent runs were performed with the differential evolution algorithm, with every 10 independent runs of these docking returning one docking pose. The 10 unbiased docking runs had been done followed by 10 results which re-ranked, to enlarge the docking accuracy, by way of the usage of a greater complicated scoring function. In this software, alongside with the docking scoring terms, a Lennard Jones 12-6 conceivable and sp2-sp2 torsion terms had been used [13a]. Based on pilot docking studies, for ranking the inhibitor poses the MolDock, re-rank scores had been chosen, and for all the oxindole derivatives and existing drugs carried out here, the poses chosen as the excellent.

This software relies on a differential evolution algorithm in which it measures MolDock score and its affinity. Here, Eq. (1) demonstrates the MolDock score energy or total $E_{\text {score }}$ measurements in which $E_{\text {inter }}$ stands for the energy of interaction between ligand and receptor. Whereas, $E_{\text {intra }}$ stands for the internal energy of the ligand. Besides this, the $E_{\text {inter }}$ can be calculated by Eq. (2). Moreover, to calculate $E_{\text {intra }}$ Eq. (3) is used. Apart from this, the estimation of steric interaction between charged atoms [12] the $E_{\mathrm{PLP}}$ (piecewise linear potential) [13b, 13c] is used.

$$
E_{\text {score }}=E_{\text {inter }}+E_{\text {intra }}
$$


Table 1: List of oxindole and its derivatives used for docking studies with COVID-19.

\begin{tabular}{|c|c|c|c|c|c|}
\hline $\begin{array}{l}\text { Ligand } \\
\text { no. }\end{array}$ & Ligand name & 2D structure & 3D structure & Active against & Reference \\
\hline OD-0 & Oxindole & & & $\begin{array}{l}\text { Antiviral, antifungal, antibacte- } \\
\text { rial, antiproliferative, anticancer, } \\
\text { anti-inflammatory, antihyperten- } \\
\text { sive, and anticonvulsant activ- } \\
\text { ities. }\end{array}$ & [9b] \\
\hline OD-1 & Strychnofoline & & & $\begin{array}{l}\text { inhibitory effects against mela- } \\
\text { noma and Ehrlich tumor cells }\end{array}$ & [14] \\
\hline OD-2 & Citrinadin A & & & anticancer & {$[15]$} \\
\hline OD-3 & $\begin{array}{l}\text { 4'-(4-bromophenyl)-5-methyl-3'- } \\
\text { (3-methyl-4-nitroisoxazol-5-yl)-5'-phe- } \\
\text { nylspiro[indoline-3,2'-pyrrolidin]-2-one }\end{array}$ & & & $\begin{array}{l}\text { inhibitory activities against } \\
\text { K562, A549, and PC- } 3 \text { cancer } \\
\text { cells }\end{array}$ & [16] \\
\hline OD-4 & $\begin{array}{l}\text { 4'-(3-bromophenyl)-5-methyl-3'- } \\
\text { (3-methyl-4-nitroisoxazol-5-yl)-5'-phe- } \\
\text { nylspiro[indoline-3,2'-pyrrolidin]-2-one }\end{array}$ & & & Anticancer & [16] \\
\hline OD-5 & $\begin{array}{l}\text { 5-methyl-3'-(3-methyl-4-nitroisoxazol- } \\
\text { 5-yl)-4',5'-diphenylspiro[indoline- } \\
\text { 3,2'-pyrrolidin]-2-one }\end{array}$ & & & $\begin{array}{l}\text { inhibitory activities against } \\
\text { K562, A549, and PC- } 3 \text { cancer } \\
\text { cells }\end{array}$ & {$[16]$} \\
\hline OD-6 & $\begin{array}{l}\text { 1-benzyl-4'-(4,6-diethoxypyrimidin- } \\
\text { 5-yl)-5-fluoro-1'-methylspiro[indoline- } \\
\text { 3,3'-pyrrolidin]-2-one }\end{array}$ & $\mathrm{Bn}$ & & anticancer activity & [17] \\
\hline OD-7 & $\begin{array}{l}\text { 1-tert-butyl 5'-ethyl 2'-methyl 2'- } \\
\text { (2-methoxy-2-oxoethyl)-4'- } \\
\text { (4-nitrophenyl)-2-oxospiro[indoline- } \\
\text { 3,3'-pyrrolidine]-1,2',5'-tricarboxylate }\end{array}$ & & & $\begin{array}{l}\text { cytotoxicities against the mouse } \\
\text { breast cancer cells } 4 T 1 \text {, colon } \\
\text { cancer cells CT26, human liver } \\
\text { cancer cells HepG2, and lung } \\
\text { cancer cells A549 }\end{array}$ & {$[18]$} \\
\hline OD-8 & $\begin{array}{l}2^{\prime} \text {-(1H-indole-3-carbonyl)-1'-(m-tolyl)- } \\
1^{\prime}, 2^{\prime}, 5^{\prime}, 6^{\prime}, 7^{\prime}, 7 \mathrm{a}^{\prime} \text {-hexahydrospiro[indo- } \\
\text { line-3,3'-pyrrolizin]-2-one }\end{array}$ & & & $\begin{array}{l}\text { cytotoxic activity against } \\
\text { HCT- } 116 \text { cells }\end{array}$ & [19] \\
\hline
\end{tabular}


Table 1: (continued)

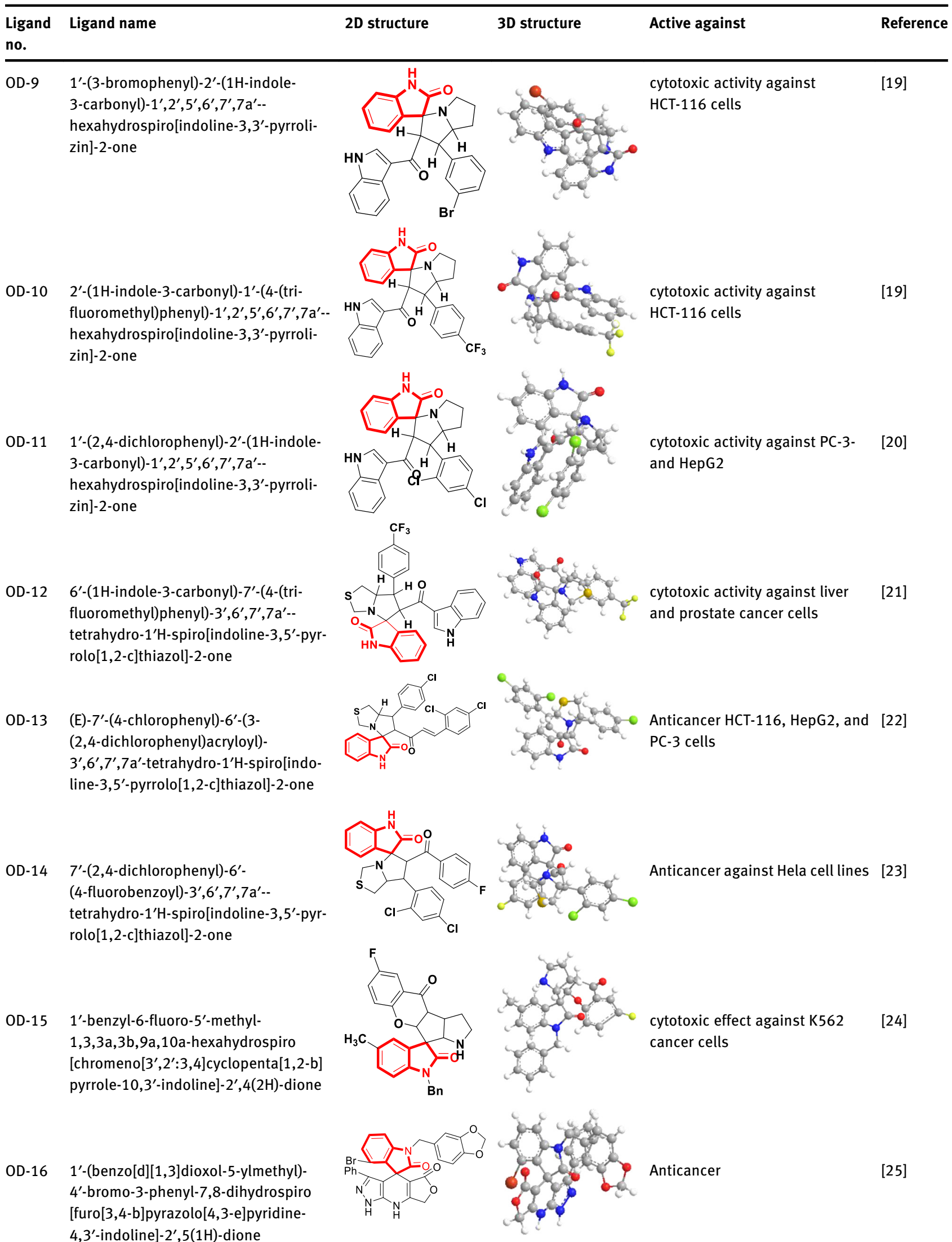


Table 1: (continued)

\begin{tabular}{l}
$\begin{array}{l}\text { Ligand } \\
\text { no. }\end{array}$ \\
\hline Ligand name \\
$\begin{array}{l}1,2^{\prime} \text {-dibenzyl-5-fluoro-2', } \\
\text { hydrospiro[indoline-3, }, 1^{\prime} \text {-pyrido[3,4-b] } \\
\text { indol]-2-one }\end{array}$ \\
OD-18 \\
$\begin{array}{l}\text { 3'-benzoyl-5'-(furan-2-yl)-4'-phenyl- } \\
\text { spiro[indoline-3,2'-pyrrolidin]-2-one }\end{array}$
\end{tabular}

OD-19 3'-benzoyl-5'-(furan-2-yl)-4'-(p-tolyl) spiro[indoline-3,2'-pyrrolidin]-2-one

OD-20 diethyl 1-benzyl-3'-ethoxy-2-oxospiro [indoline-3, $4^{\prime}$-pyrazole]-1', $5^{\prime}\left(5^{\prime} \mathrm{H}\right)$ dicarboxylate

OD-21 5'-benzyl-3'-(4-chlorophenyl)-4'-nitrospiro[indoline-3,2'-pyrrolidin]-2-one

OD-22 2'-(1,3-diphenyl-1H-pyrazol-4-yl)-1'(1H-indole-3-carbonyl)-2-oxo$1^{\prime}, 2^{\prime}, 5^{\prime}, 6^{\prime}, 7^{\prime}, 7 a^{\prime}$-hexahydrospiro[indoline-3,3'-pyrrolizine]-1'-carbonitrile

OD-23 Suitinib

OD-24 arylsulfoanilide-oxindole
2D structure

3D structure

Active against

Reference
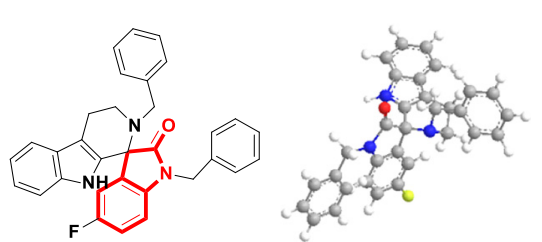

most active agent against cancer

[26] cell A549<smiles>O=C(c1ccccc1)C(c1ccccc1)C1(NC(c2ccccc2)(c2ccccc2)c2ccccc2)C(=O)Nc2ccccc21</smiles>

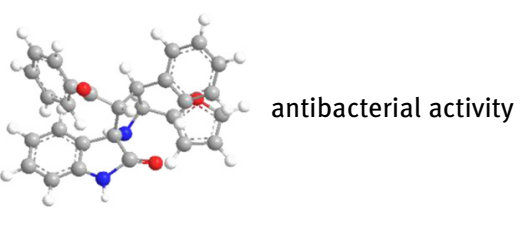<smiles>Cc1ccc(C2[C@H](c3ccco3)[C@@H](c3ccccc3)N[C@]23C(=O)Nc2ccccc23)cc1</smiles>

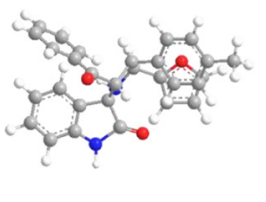

antifungal effect<smiles>CCOC(=O)C1N(C(=O)OCC)N=C(OCC)C12C(=O)N(Cc1ccccc1)c1ccccc12</smiles>

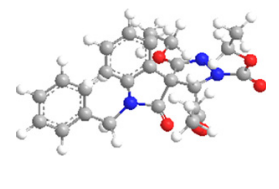
activities against Gibberella zeae and Pellicularia sasakii<smiles>O=C(O)C1(c2ccc(Cl)cc2)Nc2cc(Cc3ccccc3)ccc2NC1=O</smiles>

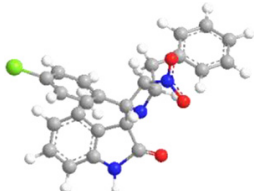

the highest activity against Escherichia coli ATCC 10536

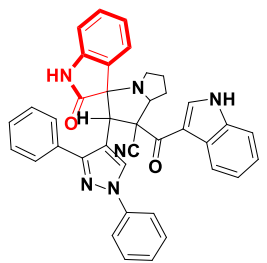

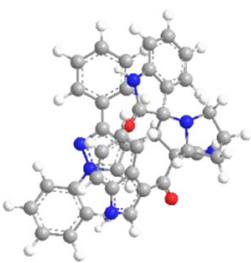

antimicrobial activity<smiles>CC(=O)c1[nH]c(/C=C2\C(=O)Nc3ccc(F)cc32)c(C)c1C</smiles>

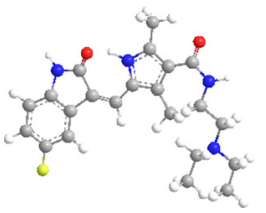

Treatment of gastrointestinal stromal tumors, and metastatic renal cell cancer.

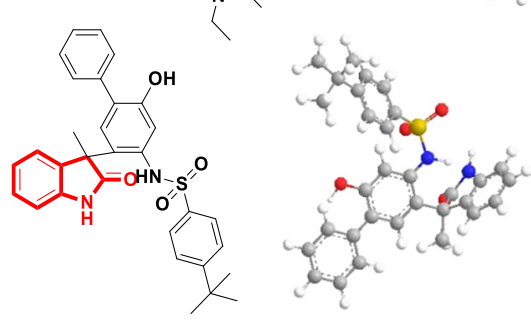

activity against lung cancer cells 
Table 1: (continued)

\begin{tabular}{|c|c|c|c|c|c|}
\hline $\begin{array}{l}\text { Ligand } \\
\text { no. }\end{array}$ & Ligand name & 2D structure & 3D structure & Active against & Reference \\
\hline OD-25 & $\begin{array}{l}1^{\prime} \text {-benzyl-5'-bromo-2,3-dihydro-1H,1" } \\
\mathrm{H}-\left[3,3^{\prime}: 3^{\prime}, 3^{\prime \prime} \text {-terbenzo[b]pyrrol]-2'(1'H)- }\right. \\
\text { one }\end{array}$ & & & $\begin{array}{l}\text { Antibacterial, antiprotozoal, } \\
\text { anti-inflammatory activities, and } \\
\text { progesterone receptors (PR) } \\
\text { agonists. }\end{array}$ & [10] \\
\hline OD-26 & $\begin{array}{l}1^{\prime} \text {-benzyl-2,3-dihydro- } 1 \mathrm{H}, 1^{\prime \prime} \mathrm{H}- \\
{\left[3,3^{\prime}: 3^{\prime}, 3^{\prime \prime} \text {-terbenzo[b]pyrrol]-2'(1'H)- }\right.} \\
\text { one }\end{array}$ & & & $\begin{array}{l}\text { Antibacterial, antiprotozoal, } \\
\text { anti-inflammatory activities, and } \\
\text { progesterone receptors (PR) } \\
\text { agonists. }\end{array}$ & [10] \\
\hline OD-27 & 3,3-Bis(2-methylindolyl)oxindole & & & $\begin{array}{l}\text { Antibacterial, antiprotozoal, } \\
\text { anti-inflammatory activities, and } \\
\text { progesterone receptors (PR) } \\
\text { agonists. }\end{array}$ & [10] \\
\hline OD-28 & $\begin{array}{l}1^{\prime} \text {-benzyl-2,2"-dimethyl-2,3-dihydro- } \\
1 \mathrm{H}, 1^{\prime \prime} \mathrm{H}-\left[3,3^{\prime}: 3^{\prime}, 3^{\prime \prime} \text {-terbenzo[b]pyrrol]- }\right. \\
2^{\prime}\left(1^{\prime} \mathrm{H}\right) \text {-one }\end{array}$ & & & $\begin{array}{l}\text { Antibacterial, antiprotozoal, } \\
\text { anti-inflammatory activities, and } \\
\text { progesterone receptors (PR) } \\
\text { agonists. }\end{array}$ & [10] \\
\hline OD-29 & $\begin{array}{l}\text { 1'-benzyl-5'-bromo-3,3"-dimethyl- } \\
{\left[2,3^{\prime}: 3^{\prime}, 2^{\prime \prime} \text {-terindolin]-2'-one }\right.}\end{array}$ & & & $\begin{array}{l}\text { Antibacterial, antiprotozoal, } \\
\text { anti-inflammatory activities, and } \\
\text { progesterone receptors (PR) } \\
\text { agonists. }\end{array}$ & [10] \\
\hline OD-30 & $\begin{array}{l}\text { 1'-benzyl-3,3"-dimethyl-5'-nitro- } \\
{\left[2,3^{\prime}: 3^{\prime}, 2^{\prime \prime} \text {-terindolin }\right]-2^{\prime} \text {-one }}\end{array}$ & & & $\begin{array}{l}\text { Antibacterial, antiprotozoal, } \\
\text { anti-inflammatory activities, and } \\
\text { progesterone receptors (PR) } \\
\text { agonists. }\end{array}$ & [10] \\
\hline
\end{tabular}

$$
\begin{aligned}
E_{\text {inter }}= & \sum_{i=\text { ligandj }=\text { protein }} \sum_{\text {intra }}\left[E_{\mathrm{PLP}}\left(r_{i j}\right)+332.0 \frac{q_{i} q_{j}}{4 r_{i j}^{2}}\right] \\
& \sum_{i=\text { ligandj } j} \sum_{\text {protein }}\left[E_{\mathrm{PLP}}\left(r_{i j}\right)\right]+\sum_{\text {flexible bond }} A\left[1-\cos \left(m \theta-\theta_{\circ}\right)\right] \\
& +E_{\text {clash }}
\end{aligned}
$$

To begin with, the explanation of Eq. (3). The First term depicts the calculation of the pair of atoms energy in the ligand, this is for those who associated with a single bond. The Second term demonstrates the torsional energy, in which $h$ stands for the torsional angle of the bond. If several torsions would be determined, so the average of its energy taken. If the distance between two heavy atoms is less than $2.0 \AA$ and allocating penalty of $1,000 \mathrm{kcal} / \mathrm{mol}$ so, the last term is used called $E$ [12]. Molegro virtual docker v.7.0.0 (MVD) is recommended by researchers due to its high accuracy when benchmarked in opposition to special reachable docking programs (MD: 87\%, Glide: 82\%, Surflex: 75\%, FlexX: 58\%) and has been tested to be worthwhile in several recent studies, also this software is cheaper and takes less time for docking result [12].

\section{Docking visualization}

Molegro Molecular Viewer version 7.0.0 (MMV) had been used to visualize molecular docking interaction between ligands (oxindole 


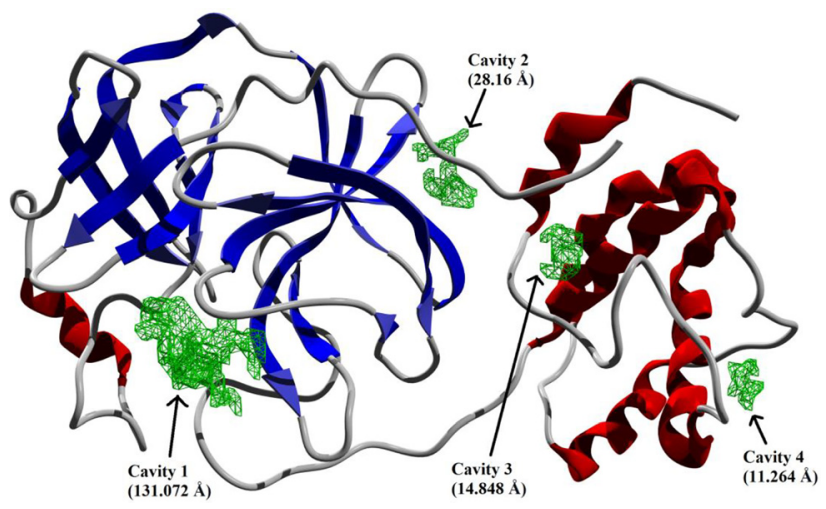

Figure 1: $M V D$ detects four cavities in the protein structure of COVID-19 (PDB ID: 6LU7), (cavity volume represents in Å), detected cavity representation: color with specifications, green: cavity, blue and red: cartoon model of COVID-19 Mpro.

derivatives) \& protein (COVID-19). It is a comprehensive software suite for analyzing and modeling molecular protein-ligand interactions, sequences, and structures.

\section{Results}

During the docking study, each ligand is selected as the best position to determine the MolDock score and Re-rank score. The MolDock score, Re-rank score, H-bonding and steric interaction between protein and ligand are represented in Table 2 (30 oxindole derivatives) [33]. Through literature it was found that compounds or ligands which exhibits lowest or minimal energy that can creates better binding with the protein [12]. Moreover, as the lowest energy needed for better binding so in this work, $-150 \mathrm{kcal} / \mathrm{mol}$ energy or minimum has been set up as the lowest energy for 30 screened ligands and from those 30 compounds 4 has been explained in depth as those compounds have the very less binding energy than the set up value. Therefore, it can be assumed that Compounds having an energy score of $-150 \mathrm{kcal} / \mathrm{mol}$ or minimal can be considered as a better inhibition agent in opposition to COVID-19.

All these 30 oxindole derivatives have binding energy less than $-150 \mathrm{kcal} / \mathrm{mol}$, but out of these 30 derivatives

Table 2: Moldock score and re-rank score (kcal/mol) for oxindole and its derivatives docked against Covid-19 crystal structure.

\begin{tabular}{|c|c|c|c|c|}
\hline Ligand no. & Energy, kcal/mol or MolDock score & $\mathrm{H}$-bond energy, $\mathrm{kcal} / \mathrm{mol}$ & Re-rank score, $\mathrm{kcal} / \mathrm{mol}$ & Steric interaction, $\mathrm{kcal} / \mathrm{mol}$ \\
\hline OD-0 (oxindole) & -77.7729 & -1.6168 & -62.0318 & -82.2444 \\
\hline OD-1 & -163.771 & -3.77584 & -92.5235 & -167.248 \\
\hline OD-2 & -170.484 & -1.87583 & -92.6507 & -173.241 \\
\hline OD-3 & -169.361 & -1.7705 & -104.855 & -150.147 \\
\hline OD-4 & -176.181 & -1.1329 & -87.028 & -159.246 \\
\hline OD-5 & -160.002 & -1.50969 & -103.628 & -139.616 \\
\hline OD-6 & -166.204 & -6.24886 & -47.7201 & -154.029 \\
\hline OD-7 & -156.367 & -4.65508 & -84.5448 & -135.626 \\
\hline OD-8 & -173.834 & -1.56657 & -110.582 & -161.009 \\
\hline OD-9 & -174.999 & -1.32644 & -109.462 & -162.196 \\
\hline OD-10 & -173.609 & -0.957101 & -59.3168 & -176.168 \\
\hline OD-11 & -169.017 & -2.5 & -107.606 & -162.098 \\
\hline OD-12 & -170.343 & -7.00791 & -107.334 & -151.814 \\
\hline OD-13 & -172.48 & -1.33883 & -92.0933 & -160.81 \\
\hline OD-14 & -156.96 & -1.33101 & -91.7567 & -161.193 \\
\hline OD-15 & -157.989 & -3.03784 & -99.0321 & -163.052 \\
\hline OD-16 & -184.135 & -4.58024 & -110.517 & -164.734 \\
\hline OD-17 & -165.005 & -0.16204 & -116.114 & -177.738 \\
\hline OD-18 & -157.983 & -1.73442 & -87.8769 & -147.773 \\
\hline OD-19 & -163.664 & -4.59035 & -86.8019 & -149.275 \\
\hline OD-20 & -152.96 & -7.17037 & -108.495 & -149.54 \\
\hline OD-21 & -156.81 & -2.5 & -45.454 & -149.047 \\
\hline OD-22 & -200.409 & -1.46148 & -98.8471 & -176.936 \\
\hline OD-23 & -156.06 & -1.95791 & -112.799 & -150.456 \\
\hline OD-24 & -170.595 & -2.5 & -64.1252 & -180.03 \\
\hline OD-25 & -169.075 & -7.70789 & -38.7846 & -154.652 \\
\hline OD-26 & -162.18 & 0.0660138 & -85.5848 & -158.896 \\
\hline OD-27 & -170.559 & -7.79817 & -40.3453 & -160.858 \\
\hline OD-28 & -164.975 & -3.2521 & -50.5513 & -162.292 \\
\hline OD-29 & -162.531 & -1.57598 & -75.1988 & -163.25 \\
\hline OD-30 & -165.828 & -2.58528 & -109.239 & -171.215 \\
\hline
\end{tabular}


OD-22 ligand, OD-16 ligand, OD-4 ligand, and OD-9 ligand revealed the most lowest MolDock score which is $-200.409 \mathrm{kcal} / \mathrm{mol},-184.135 \mathrm{kcal} / \mathrm{mol},-176.181$ $\mathrm{kcal} / \mathrm{mol}$ and $-174.999 \mathrm{kcal} / \mathrm{mol}$ respectively, whereas oxindole(OD-0) revealed MolDock score -77.7729 $\mathrm{kcal} / \mathrm{mol}$. Moreover, the other 26 derivatives also exhibited better binding energy as compared to OD-0.

Interaction of core oxindole with protein has been shown in Figure 2(OD-0). While, Interactions of these four oxindole derivatives which are OD-22, OD-16, OD-4 and OD-9 shown in Figures 3-6, respectively. Each figure demonstrates the optimum score of the docking, Amino acids in the active site which are presented in wireframe with element color (where oxygen is red, carbon is gray, nitrogen is blue, hydrogen is white and sulfur is yellow) and the ligand is represented in Stick lines with fix color yellow. Hydrogen bonds illustrate between ligand and active site of Covid-19 Mpro by the blue lines.

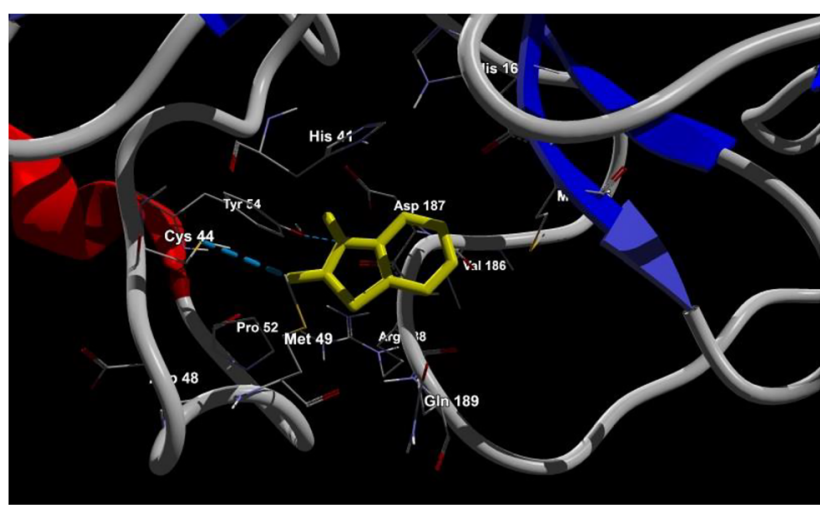

Figure 2: Oxindole ligand docked against the crystal protein structure of COVID-19 main protease (Mpro).

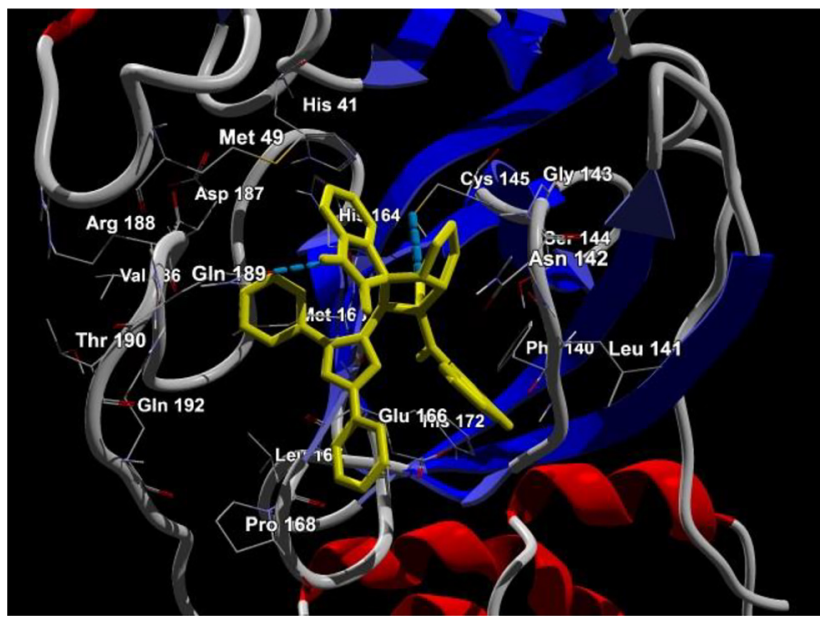

Figure 3: OD-22 ligand docked against the crystal protein structure of COVID-19 main protease (Mpro).
Ligand OD-22 has the lowest MolDock score, Re-rank score, and steric interaction energy in comparison with other ligands, with COVID-19 main protease. These four (OD-22, OD-16, OD-4, OD-9) ligands well fit in the active sites of the protein. Figure 7, illustrates hydrogen bonding

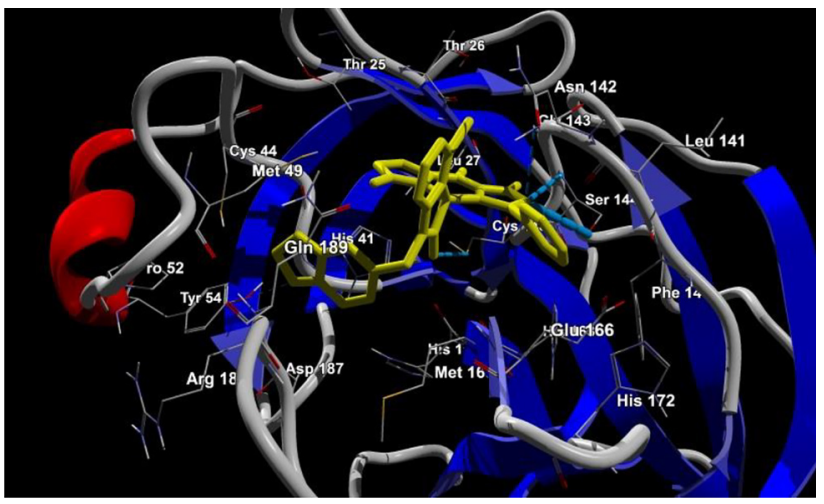

Figure 4: $O D-16$ ligand docked against the crystal protein structure of COVID-19 main protease (Mpro).

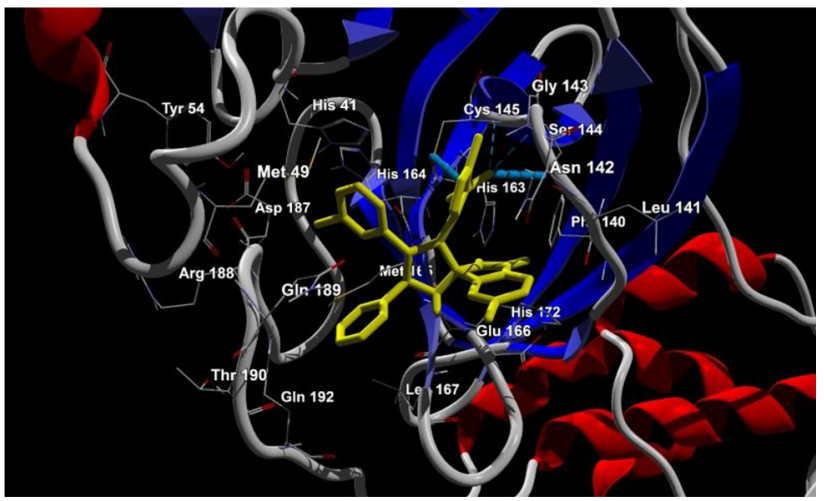

Figure 5: OD-4 ligand docked against the crystal protein structure of COVID-19 main protease (Mpro).

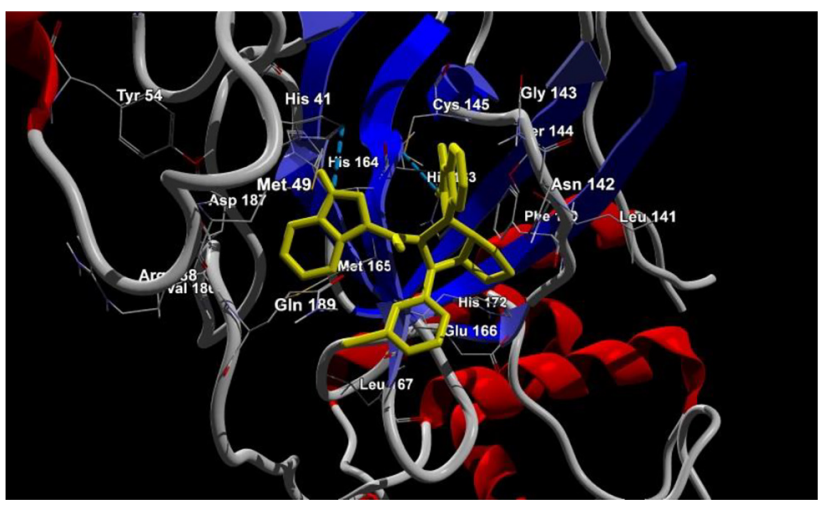

Figure 6: OD-9 ligand docked against the crystal protein structure of COVID-19 main protease (Mpro). 
with amino acids of coronavirus protein, Figure 8 shows, steric interaction with residues of COVID-19 protein, and Figure 9 represents the comparison of the binding of Oxindole, OD-22, OD-16, OD-4, and OD-9 ligands in the active sites of COVID-19 main protease(Mpro). It depicted clear binding of Oxindole(OD-0), OD-22, OD-16, OD-4, and OD-9 ligands. In this work, a comprehensive analysis of the ligand-protein interaction of OD-22, OD-16, OD-4, and OD-9 ligands are presented in Table 3 which includes protein-ligand interaction score, residues, and distance of interaction energy. Moreover, Table 4 elicits the steric interaction of the four oxindole derivatives with amino acids and atoms, furthermore, the interacting distance and strength also represented in the same table. Overall, these four derivatives show the highest steric interaction and H-bonding which provides better MolDock score and hence, among the 30 oxindole derivatives these four derivatives are the best. Along with this study, comparative study of oxindole derivatives against Drugs under clinical trials and some already given to the infected patients, the name of the drugs are favipiravir, hydroxychloroquine sulfate, lopinavir, and remdesivir have been done on the same protein of COVID-19 through MVD v.7.0.0 [34]. The docking results of these four drugs are illustrated in Table 5 which is a Moldock score and Tables 6 and 7 elicits hydrogen bonding and steric interactions respectively. These four drugs shows poor results in docking as compared to oxindole derivatives.

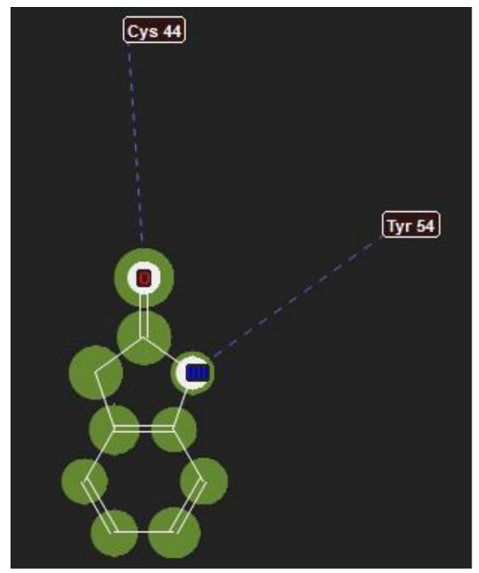

(A): Oxindole

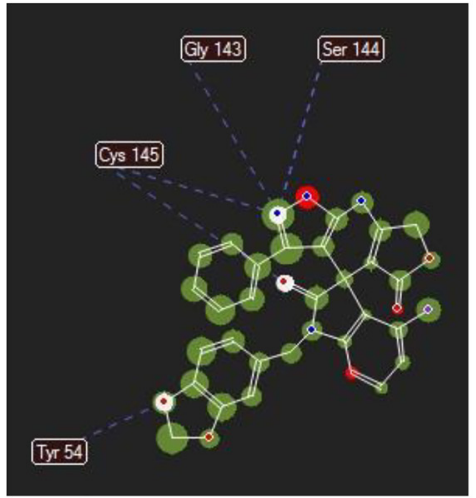

(C): OD-16 ligand

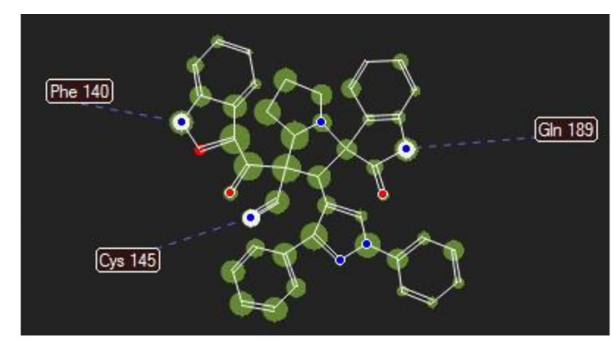

(B): OD-22 ligand

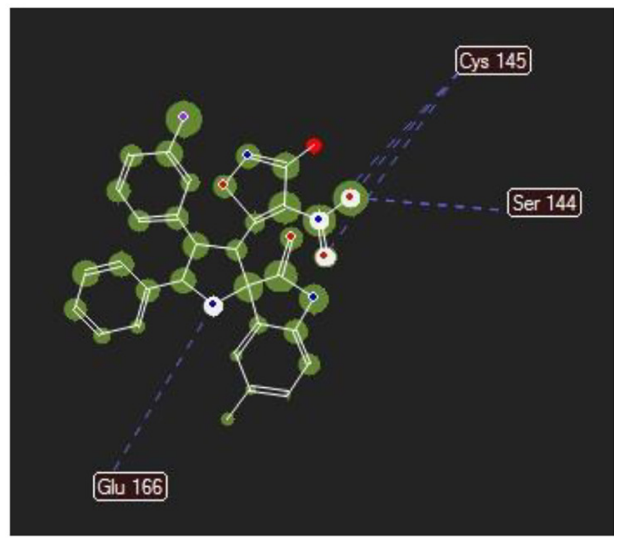

(D): OD-4 ligand

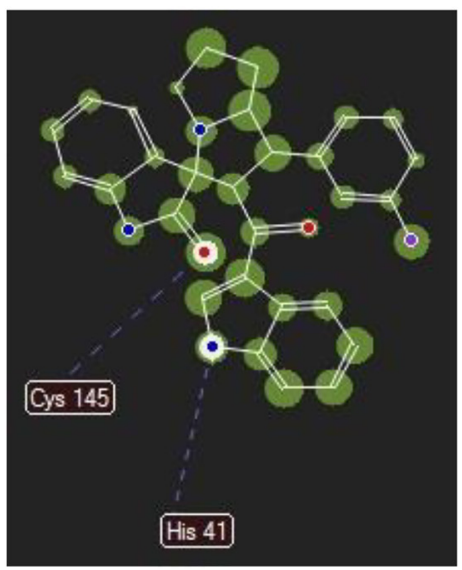

(E): OD-9 ligand
Figure 7: (A-E): Hydrogen bond interaction with Covid-19 of oxindole (A), OD-22 ligand (B), OD-16 ligand (C), OD-4 ligand (D) and OD-9 ligand $(E)$. 


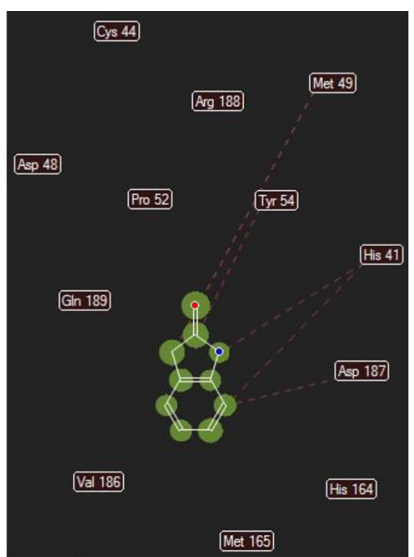

(A): Oxindole

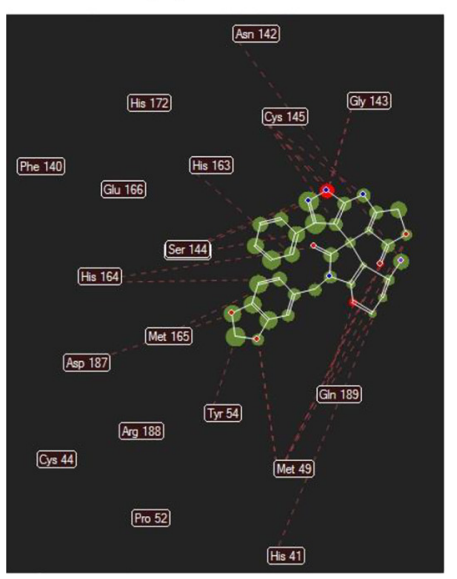

(C): OD-16 ligand

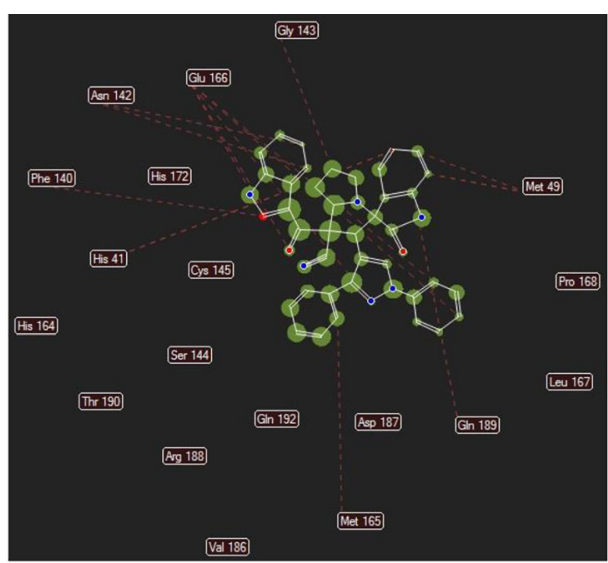

(B): OD-22 ligand

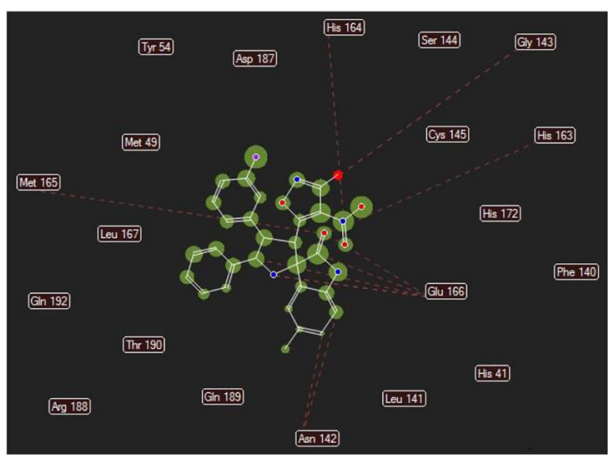

(D): OD-4 ligand

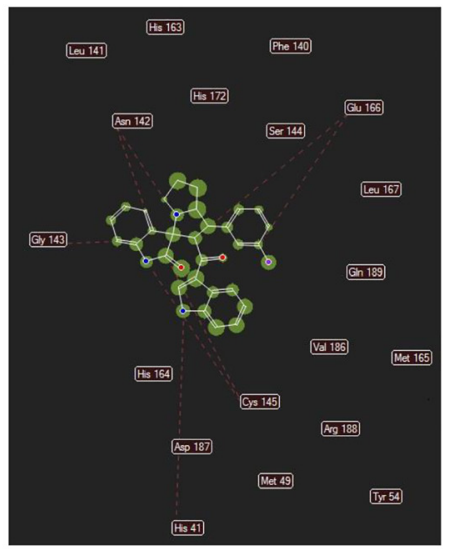

(E): OD-9 ligand
Figure 8(A-E): Steric interaction with Covid19 of oxindole (A), OD-22 ligand (B), OD-16 ligand (C), OD-4 ligand (D) and OD-9 ligand (E).

\section{Discussion}

To begin with the depth explanation of each of these ligands with COVID-19 protein(PDB:6LU7). Amino acids Gln 189 , Cys 145, and Phe 140 are strongly bound with OD-22 (Figure 3). Whereas, OD-16 tightly interacts with Ser 144, Cys 145, Gly 143, and Tyr 54 (Figure 4). Furthermore, H-bond formation has been seen with '-NH' and Carbonitrile group of compound OD-22 which consists of amino acids Gln 189, Phe 140, and Cys 145 respectively. Apart from this, OD-16 produces H-bond with '-NH' group and the amino acids are Ser 144, Cyr 145, and Gly 143. In the OD-16 one noticeable observation seen that is an amino acid, Tyr 54 interacts with 'O' atom (Figure 7B, C). Besides this, steric interactions with both of these ligands have been observed, in which interacting residues Met 49, Gln 189, Met 165, His 41, Phe 140, Asn 142, Glu 166, and Gly 143 for OD-22 ligand and Gly 143, Asn 142, Cys 145, His 163, Ser 144, His 164, Met 165, Asp 187, Tyr 54, Met 49, Gln 189 and His 41 for OD-16 ligand (Figure 8B, C). Here, OD-22 ligand has the lowest energy as compared to OD-16 due to less steric interactions and H-bonding in OD-16 ligand. 


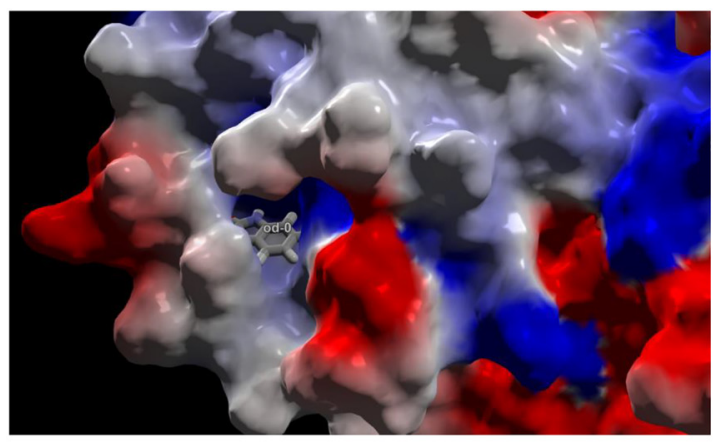

(A): Oxindole

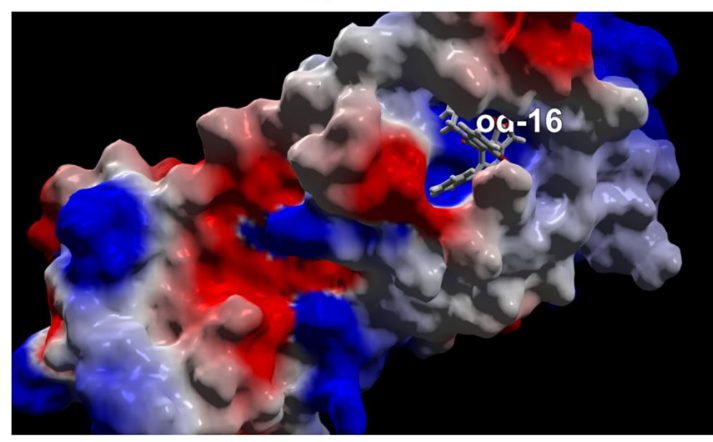

(C): OD-16 ligand

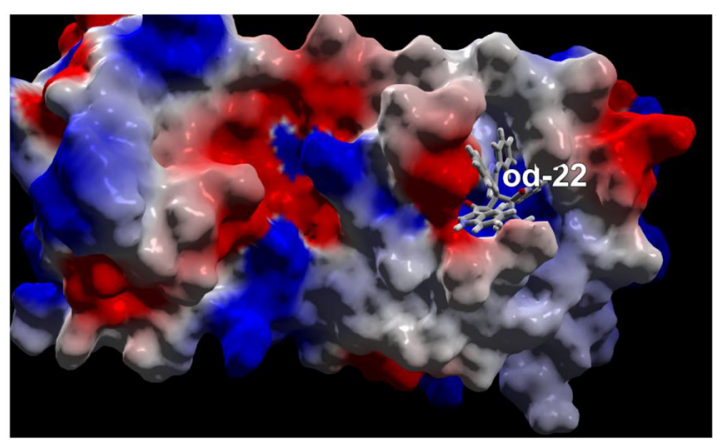

(B): OD-22 ligand

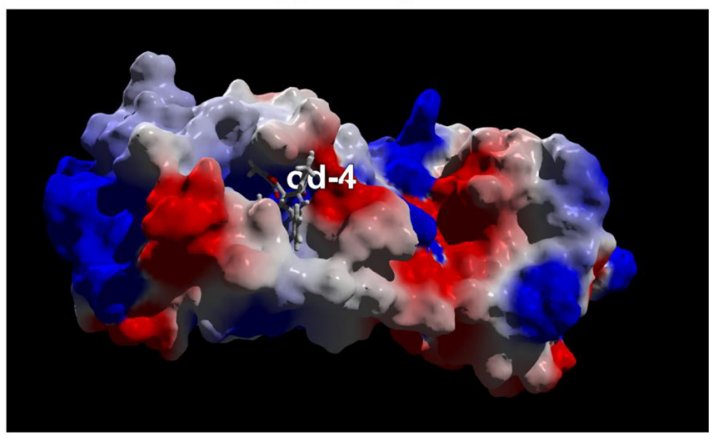

(D): OD-4 ligand

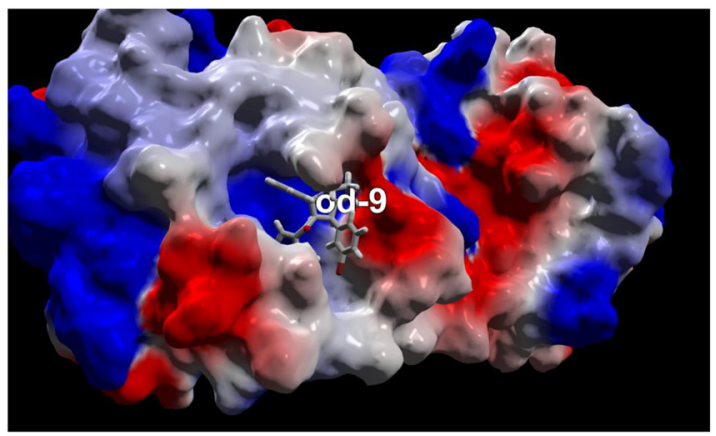

(E): OD-9 ligand

Figure 9: (A-E): Binding of oxindole (A), OD-22 ligand (B), OD-16 ligand (C), OD-4 ligand (D) and OD-9 ligand (E) in the binding sites of COVID-19 main protease (Mpro) (PDB ID: 6LU7) with clear surfaces.

In addition to this, another two ligands OD-4 and OD-9 showcase satisfactory energies but not less than OD-22 and OD-16. Moreover, three H-bonding occurs between active residues Cys 145, Ser 144, and Glu 166 with 'O' atom present in OD-4 also, $\mathrm{H}$-bond interaction seen with amino acids Glu 166 with '-NH' group of the same ligand. While considering the H-bonding of OD-9, observed only two H-bond interaction with active residue Cyr 145 with 'O' atom and His 41 '-NH' group of OD-9 (Figure 7D, E). To add with this, steric interactions of OD-4 with residues His 164, Gly 143, His 163, Glu 166, Asn 142, and Met 165 involved in the interaction and OD-9 exhibits steric interactions with active residues Asn 142, Glu 166, Cys 145, His 41, and Gly 143 (Figure 8D, E). The binding interactions of OD- 4 and OD-9 have been illustrated in Figures 5 and 6, respectively.
However, the simulation study of these existing drugs through MVD on COVID-19 protein reveals the energy $-66.2854 \mathrm{kcal} / \mathrm{mol},-97.2365 \mathrm{kcal} / \mathrm{mol},-121.56 \mathrm{kcal} / \mathrm{mol}$, and $-161.435 \mathrm{kcal} / \mathrm{mol}$ respectively (Table 5), these energies(Moldock scores) are very high as compared to energies received by four oxindole derivatives. Moreover, these drugs elicit very less H-bonding and steric interaction (Figure 11 and Tables 6 and 7) as compared to four oxindole derivatives this is because the interacting distance of the bond is high so, these drugs cannot bind tightly with protein as compared to four ligands of oxindole. Here, the favipiravir forms two H-bonds with residues Cys 145 and Ser 144 and only one amino acid Leu 141 shows steric interaction with protein (Figure 11A). Whereas, Hydroxychloroquine sulfate produces only one $\mathrm{H}$-bond and two 
208

Shah et al.: Molecular docking of oxindole derivatives

DE GRUYTER

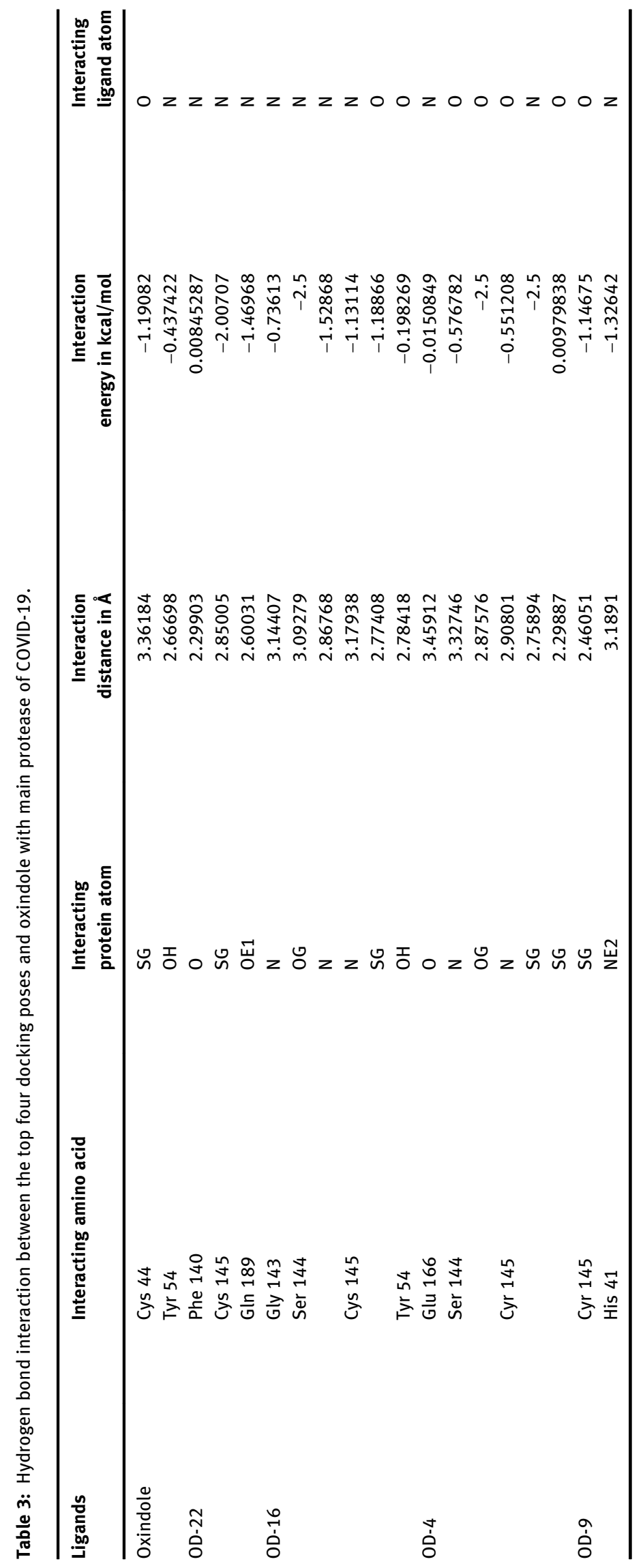


Table 4: Steric interaction between the top four docking poses and oxindole with main protease of COVID-19.

\begin{tabular}{|c|c|c|c|c|}
\hline Ligands & Interacting amino acid & Interaction distance in $\AA$ & Strength & Interacting ligand atom \\
\hline \multirow[t]{5}{*}{ Oxindole } & Met 49 & 3.22 & 0.47 & C \\
\hline & Tyr 54 & 2.92 & 2.29 & C \\
\hline & His 41 & 2.85 & 2.74 & $\mathrm{~N}$ \\
\hline & & 3.18 & 0.71 & C \\
\hline & Asp 187 & 3.29 & 0.06 & C \\
\hline \multirow[t]{13}{*}{ OD-22 } & Met 49 & 3.14 & 0.99 & C \\
\hline & & 3.19 & 0.75 & C \\
\hline & Gln 189 & 3.26 & 0.21 & $\mathrm{~N}$ \\
\hline & Met 165 & 3.22 & 0.49 & C \\
\hline & His 41 & 2.77 & 3.22 & C \\
\hline & Phe 140 & 2.39 & 5.54 & C \\
\hline & Asn 142 & 2.92 & 2.32 & C \\
\hline & & 2.93 & 2.24 & C \\
\hline & Glu 166 & 2.96 & 2.08 & $\mathrm{~N}$ \\
\hline & & 2.86 & 2.68 & 0 \\
\hline & & 2.71 & 3.58 & C \\
\hline & & 3.30 & 0.02 & C \\
\hline & Gly 143 & 2.99 & 1.89 & C \\
\hline \multirow[t]{18}{*}{ OD-16 } & Gly 143 & 2.87 & 2.60 & $\mathrm{~N}$ \\
\hline & Asn 142 & 3.29 & 0.08 & $\mathrm{~N}$ \\
\hline & Cys 145 & 3.25 & 0.32 & C \\
\hline & & 2.67 & 3.84 & $\mathrm{~N}$ \\
\hline & & 3.26 & 0.24 & $\mathrm{~N}$ \\
\hline & His 163 & 3.13 & 1.00 & C \\
\hline & Ser 144 & 2.17 & 3.59 & $\mathrm{~N}$ \\
\hline & His 164 & 3.19 & 0.67 & C \\
\hline & & 2.21 & 6.58 & 0 \\
\hline & Met 165 & 3.24 & 0.39 & C \\
\hline & Asp 187 & 2.93 & 2.25 & 0 \\
\hline & Tyr 54 & 3.12 & 1.08 & C \\
\hline & Met 49 & 2.82 & 2.91 & 0 \\
\hline & & 3.23 & 0.40 & C \\
\hline & & 3.01 & 1.78 & 0 \\
\hline & Gln 189 & 3.29 & 0.07 & C \\
\hline & & 2.74 & 3.39 & C \\
\hline & His 41 & 3.16 & 0.87 & 0 \\
\hline \multirow[t]{10}{*}{ OD-4 } & His 164 & 2.99 & 1.87 & 0 \\
\hline & Gly 143 & 2.29 & 6.14 & C \\
\hline & His 163 & 3.10 & 1.19 & 0 \\
\hline & Glu 166 & 2.75 & 3.33 & $\mathrm{~N}$ \\
\hline & & 3.17 & 0.77 & C \\
\hline & & 3.30 & 0.02 & C \\
\hline & & 3.18 & 0.72 & 0 \\
\hline & Asn 142 & 3.18 & 0.73 & C \\
\hline & & 3.10 & 1.19 & C \\
\hline & Met 165 & 3.15 & 0.88 & 0 \\
\hline \multirow[t]{8}{*}{ OD-9 } & Asn 142 & 3.12 & 1.11 & C \\
\hline & & 2.67 & 3.82 & C \\
\hline & Glu 166 & 3.30 & 0.03 & C \\
\hline & & 3.18 & 0.74 & C \\
\hline & Cys 145 & 2.88 & 2.56 & $\mathrm{~N}$ \\
\hline & & 2.92 & 2.31 & 0 \\
\hline & His 41 & 3.21 & 0.56 & $\mathrm{~N}$ \\
\hline & Gly 143 & 3.11 & 1.17 & C \\
\hline
\end{tabular}


Table 5: Moldock score and re-rank score $(\mathrm{kcal} / \mathrm{mol})$ for existing drugs docked against Covid-19 crystal structure.

\section{Structure and name}

(c)

Favipiravir

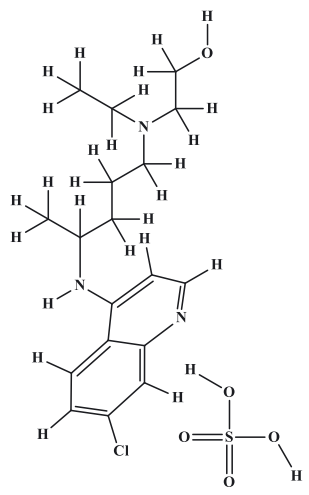

Hydroxychloroquine sulfate
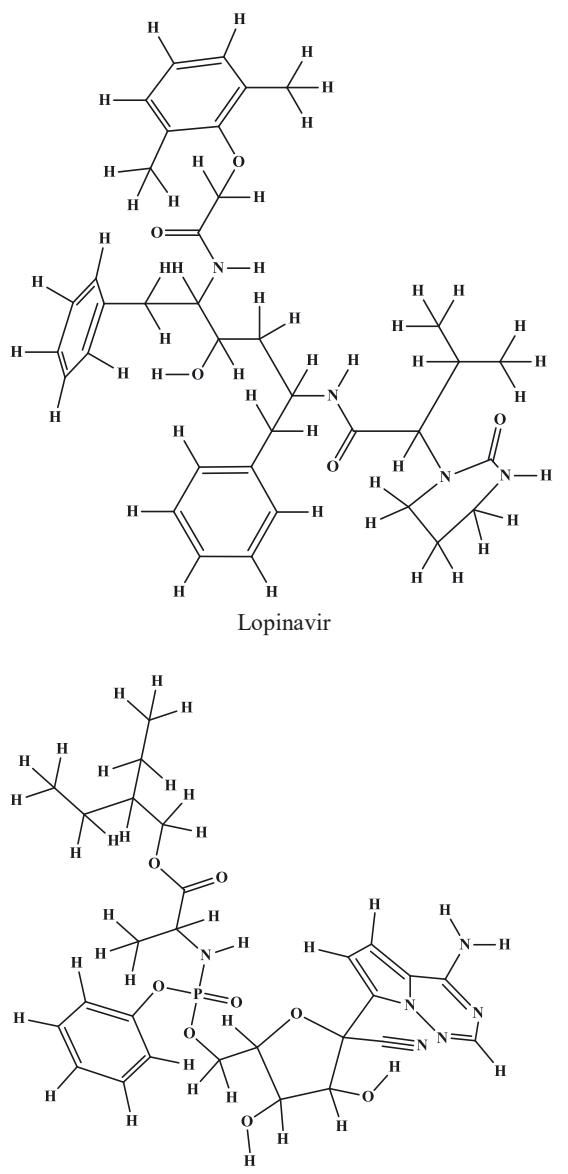

Remdesivir
Energy, kcal/mol or Mol-

Dock score

$-66.2854$

$-97.2365$

$-121.56$

$-3.4934$

$-27.2975$

$-142.699$

$-161.435$

$-3.08106$

$-93.7058$

$-169.918$

$-115.542$

$-72.0991$ 
Table 6: Hydrogen bond interaction between the existing drugs with main protease of COVID-19.

\begin{tabular}{|c|c|c|c|c|c|}
\hline Ligands & $\begin{array}{l}\text { Interacting } \\
\text { amino acid }\end{array}$ & $\begin{array}{l}\text { Interacting } \\
\text { protein atom }\end{array}$ & $\begin{array}{r}\text { Interaction } \\
\text { distance in } \AA\end{array}$ & $\begin{array}{r}\text { Interaction } \\
\text { energy in } \mathrm{kcal} / \mathrm{mol}\end{array}$ & $\begin{array}{l}\text { Interacting } \\
\text { ligand atom }\end{array}$ \\
\hline \multirow[t]{3}{*}{ Favipiravir } & Ser 144 & 0 & 2.6911 & -2.5 & 0 \\
\hline & & 0 & 2.78258 & -1.76444 & $\mathrm{~N}$ \\
\hline & Cys 145 & SG & 2.99713 & -2.5 & 0 \\
\hline Hydroxychloroquine sulfate & Arg 188 & 0 & 3.16446 & -1.4 .7919 & 0 \\
\hline \multirow[t]{3}{*}{ Lopinavir } & Glu 166 & $\mathrm{~N}$ & 3.20761 & -1.00045 & 0 \\
\hline & Gln 189 & 0 & 2.5992 & -2.4933 & 0 \\
\hline & Cys 145 & SG & 2.77426 & -2.40251 & 0 \\
\hline \multirow[t]{4}{*}{ Remdesivir } & Leu 141 & 0 & 2.59869 & -0.67137 & $\mathrm{~N}$ \\
\hline & Ser 144 & OG & 3.32199 & -1.39004 & 0 \\
\hline & Cys 145 & $\mathrm{~N}$ & 2.73746 & -1.14734 & 0 \\
\hline & & SG & 2.66863 & -1.64397 & 0 \\
\hline
\end{tabular}

Table 7: Steric interaction between the existing drugs with main protease of COVID-19.

\begin{tabular}{|c|c|c|c|c|}
\hline Ligands & $\begin{array}{l}\text { Interacting } \\
\text { amino acid }\end{array}$ & $\begin{array}{r}\text { Interaction } \\
\text { distance in } \AA\end{array}$ & Strength & $\begin{array}{l}\text { Interacting } \\
\text { ligand atom }\end{array}$ \\
\hline \multirow[t]{2}{*}{ Favipiravir } & Ser 144 & 3.14 & 0.97 & $\mathrm{~N}$ \\
\hline & Leu 141 & 3.15 & 0.94 & $\mathrm{C}$ \\
\hline \multirow{2}{*}{$\begin{array}{l}\text { Hydroxychloroquine } \\
\text { sulfate }\end{array}$} & Thr 26 & 2.76 & 3.25 & $\mathrm{~N}$ \\
\hline & Cys 145 & 3.13 & 1.01 & $C$ \\
\hline \multirow[t]{4}{*}{ Lopinavir } & His 163 & 2.76 & 3.29 & $C$ \\
\hline & Phe 140 & 2.56 & 4.51 & $C$ \\
\hline & Met 165 & 2.96 & 2.06 & 0 \\
\hline & Met 49 & 2.44 & 5.18 & $C$ \\
\hline \multirow[t]{5}{*}{ Remdesivir } & Asn 142 & 3.13 & 1.02 & $\mathrm{C}$ \\
\hline & Thr 26 & 2.38 & 5.57 & $C$ \\
\hline & Gly 143 & 3.00 & 1.83 & $\mathrm{C}$ \\
\hline & & 2.67 & 3.80 & $C$ \\
\hline & & 3.04 & 1.55 & $\mathrm{C}$ \\
\hline
\end{tabular}

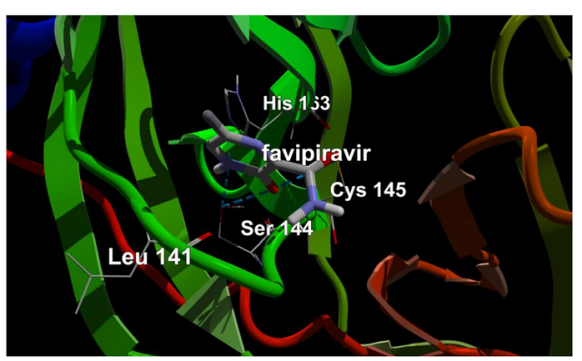

(A) Favipiravir

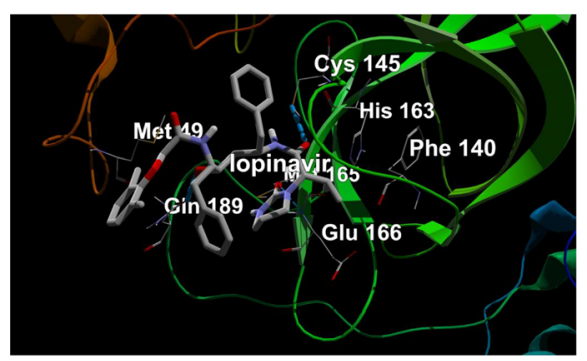

(C) Lopinavir

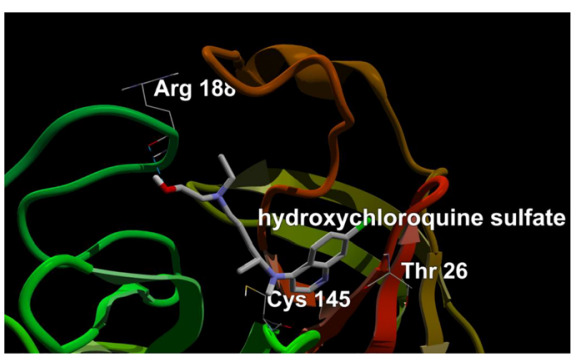

(B) Hydroxychloroquine sulfate

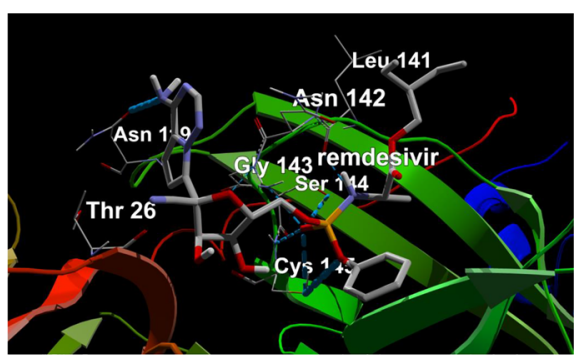

(D) Remdesivir
Figure 10: (A-D): Binding of Favipiravir (A), Hydroxychloroquine sulfate (B), Lopinavir (C) and Remdesivir (D) in the binding sites of COVID-19 main protease (Mpro) (PDB ID: 6LU7), in which amino acids in wireframe with element color, ligands in stick with element color, and cartoon model as backbone of protein. 


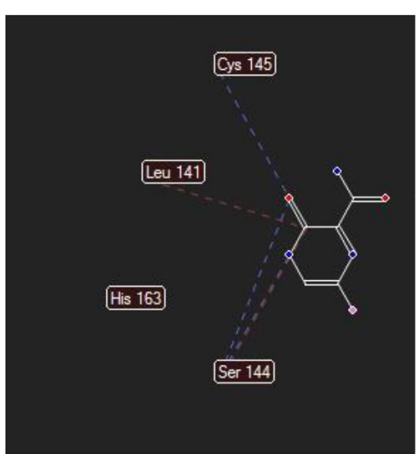

(A) Favipiravir

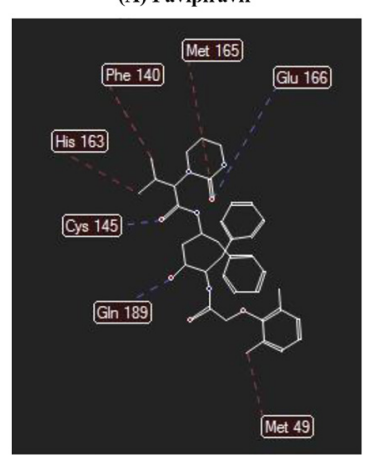

(C) Lopinavir

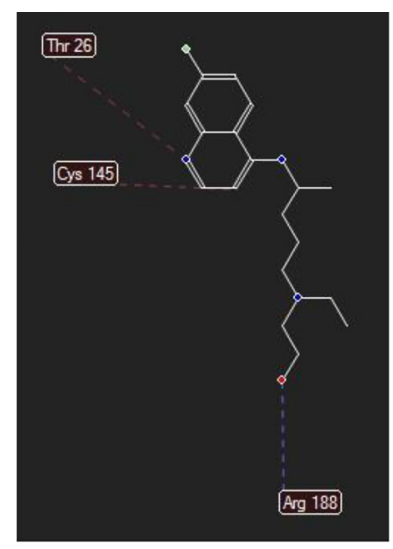

(B) Hydroxychloroquine sulfate

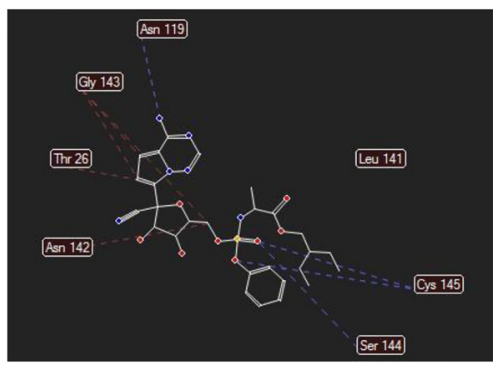

(D) Remdesivir
Figure 11: (A-D): Hydrogen bond interaction (blue line) and steric interaction (red line) with Covid-19 of Favipiravir (A), Hydroxychloroquine sulfate (B), Lopinavir (C) and Remdesivir (D).
Table 8: Comparative protein-ligand binding energy of existing drugs and four oxindole derivatives through MVD.

\begin{tabular}{lrlr}
\hline Ligand & $\begin{array}{r}\text { Energy, Existing } \\
\text { kcal/mol or } \\
\text { Moldrugs } \\
\text { Mock score }\end{array}$ & $\begin{array}{r}\text { Energy, } \\
\text { kcal/mol or } \\
\text { MolDock } \\
\text { score }\end{array}$ \\
\hline OD-0 & -77.7729 & Favipiravir & -66.2854 \\
OD-22 & -200.409 & Hydroxychloroquine & -97.2365 \\
& & sulfate & \\
OD-16 & -184.135 & Lopinavir & -121.56 \\
OD-4 & -176.181 & Remdesivir & -161.435 \\
OD-9 & -174.999 & & \\
\hline
\end{tabular}

steric interactions with residues Arg 188 and Cys 145, Thr 26 respectively. Apart from this, Lopinavir and remdesivir both exhibit more $\mathrm{H}$-bonding and steric interactions as compared to favipiravir and hydroxychloroquine sulfate but not more than OD-22, OD-16, OD-4 and, OD-9 ligands. Amino acids Glu 166, Cys 145, and Gln 189 are responsible to form H-bonding also residues Met 165, Phe 140, His 163 and, Met 49 are for steric interaction with lopinavir (Figure 11C). Furthermore, remdesivir forms three H-bond and three steric interactions with amino acids Asn 119, Cys 145, Ser 144 and, Gly 143, Thr 26, Asn 142 respectively
(Figure 11D). To add with this, after analyzing the docking data of these drugs one common outcome observed that is amino acid 'Cys 145' of COVID-19 protein forms H-bond with ligands whether ligand is oxindole derivatives or existing drugs. Overall, the binding interaction pattern is represented in Figure 10. Indeed, as per the data received through the docking of these four drugs with COVID-19 protein, it can be claimed that oxindole derivatives would be a better option to treat COVID-19 patients. In addition to this, Table 8 illustrates the comparative data in terms of Moldock scores of recent existing drugs for coronavirus prevention and the proposed work.

\section{Conclusions}

All in all, it can be stated that the rapid spreading of coronavirus at every hook and corner of the world attracts every researcher for the invention that can use to cure this outbreak of novel coronavirus. Henceforth, this research related to molecular docking based on virtual screening was conducted to classify heterocyclic compounds (oxindole derivatives) having the potential to bind the main protease crystallized protein structure of COVID-19 (PDB ID: 6LU7). In addition to this, a comparative study has been 
conducted on existing drugs that are under clinical trial for the prevention of this threatening virus with oxindole derivatives. Based on the molecular docking study, results that obtained it can be highlighted that the oxindole derivatives able to interact with all the significant amino acids of COVID-19 protein structure. According to MolDock binding score oxindole derivatives bearing excellent binding potency against COVID-19 due to its pharmacology properties. In this presented work, among 30 compounds, four oxindole derivatives (OD-22, OD-16, OD-4, OD-9) exhibit the lowest binding energy $(-200.409 \mathrm{kcal} / \mathrm{mol}$, $-184.135 \mathrm{kcal} / \mathrm{mol},-176.181 \mathrm{kcal} / \mathrm{mol},-174.999 \mathrm{kcal} / \mathrm{mol}$ ), as well as compounds, fit well in the binding sites of COVID-19 Mpro crystallized protein structure and also interact with the residues in the active sites, which are essential for their biological activity. Apart from this, these derivatives are proven to be more efficient than existing drugs in terms of Molock scores and other parameters. Thus, oxindole derivatives might be an effective inhibitor of the main protease of COVID-19 also it would be used as an antiviral drug agent. Furthermore, in the upcoming years, studies should be conducted for the validation of these compounds using in vitro and in vivo models which will be useful for new drug inventory against coronavirus.

Acknowledgments: The authors are thankful to Kanupriya Singh Rathore, President and Ravindra Singh Rathore, Vice-President, ITM (SLS) Baroda University, Vadodara, India for their valuable guidance and support.

Research funding: None declared.

Author contributions: All authors have accepted responsibility for the entire content of this manuscript and approved its submission.

Competing interests: Authors state no conflict of interest. Informed consent: Not applicable.

Ethical approval: Not applicable.

\section{References}

1. Zhou P, Yang XL, Wang XG, Hu B, Zhang L, Zhang W, et al. A pneumonia outbreak associated with a new coronavirus of probable bat origin. Nature 2020;579:270-3.

2. Chen Y, Liu Q, Guo D. Emerging coronaviruses: genome structure, replication, and pathogenesis. J Med Virol 2020;92:418-23.

3. WHO. Coronavirus disease (COVID-2019) situation reports. Available from: https://www.who.int/emergencies/diseases/ novel-coronavirus-2019/situation-reports [Accessed 11 Aug 2020].

4. Mohammadi N, Shaghaghi N. Inhibitory effect of eight secondary metabolites from conventional medicinal plants on COVID_19 virus protease by molecular docking analysis. ChemRxiv Preprint 2020. 11987475:v1.

5. Tan W, Zhao X, Ma X, Wang W, Niu P, Xu W, et al. A novel coronavirus genome identified in a cluster of pneumonia casesWuhan, China 2019-2020. China CDC Weekly 2020;2:61-2.

6. Pharmaceutical Technology. Glenmark gets regulatory approval for Favipiravir to treat Covid-19. Available from: https://www. pharmaceutical-technology.com/news/glenmark-favipiravircovid-nod/ [Accessed 22 June 2020].

7. (a) Grinter SZ, Zou X. Challenges, applications, and recent advances of protein-ligand docking in structure-based drug design. Molecules 2014;19:10150-76. (b) Mukesh B, Rakesh K. Molecular docking: a review. Int J Res Ayurveda Pharm 2011;2: 1746-51.

8. (a) Al-Mulla A. A review: biological importance of heterocyclic compounds. Der Pharma Chem 2017;9:141-72. (b) Demirayak S, Kayagil I, Yurttas L. Microwave supported synthesis of some novel 1, 3-diarylpyrazino [1, 2-a] benzimidazole derivatives and investigation of their anticancer activities. Eur J Med Chem 2011; 46:411-6. (c) Ito H, Sakakibara J, Ueda T. Antitumor effect of 6-phenyl-7 (6H)-isoselenazolo [4,3-d] pyrimidone on the growth of Ehrlich ascites tumor. Cancer Lett 1985;28:61-8.

9. (a) Kaur M. Oxindole: a nucleus enriched with multitargeting potential against complex disorders. In: Silakari O, editor. Key heterocycle cores for designing multitargeting molecules. Elsevier; 2018. (b) Rudrangi SR, Bontha VK, Manda VR, Bethi S. Oxindoles and their pharmaceutical significance-an overview. Asian J Res Chem 2011;4: 335-8.

10. (a) Nasseri MA, Ahrari F, Zakerinasab B. Nickel oxide nanoparticles: a green and recyclable catalytic system for the synthesis of diindolyloxindole derivatives in aqueous medium. RSC Adv 2015;5:13901-5. (b) Patel GM, Deota PT. Tungstic acidcatalyzed synthesis of 3, 3-bis (1H-indol-3-yl) indolin-2-one derivatives. Heterocycl Commun 2013;19:421-4.

11. (a) Jin Z, Du X, Xu Y, Deng $Y$, Liu M, Zhao Y, et al. Structure of $M$ pro from SARS-CoV-2 and discovery of its inhibitors. Nature 2020;582:289-93. (b) RCSB PDB. The crystal structure of COVID-19 main protease in complex with an inhibitor N3. Available from: http://www.rcsb.org/structure/6LU7. [Accessed 05 Feb 2020].

12. Thomsen R, Christensen MH. MolDock: a new technique for high-accuracy molecular docking. J Med Chem 2006;49: 3315-21.

13. (a) Naeem S, Hylands P, Barlow D. Docking studies of chlorogenic acid against aldose reductase by using Molgro virtual docker software. J Appl Pharm Sci 2013;3:13-20. (b) Gehlhaar DK, Verkhivker G, Rejto PA, Fogel DB, Fogel LJ, Freer ST. Docking conformationally flexible small molecules into a protein binding site through evolutionary programming. In: Proceedings of the Fourth International Conference on Evolutionary Programming. Lect Notes Comput Sci; 1995, vol 1447: p. 449-61. (c) Yang JM, Chen CC. GEMDOCK: a generic evolutionary method for molecular docking. Proteins 2004;55:288-304.

14. Yu Q, Guo P, Jian J, Chen Y, Xu J. Nine-step total synthesis of (-)-strychnofoline. Chem Comm 2018;54:1125-8.

15. (a) Tsuda M, Kasai Y, Komatsu K, Sone T, Tanaka M, Mikami Y, et al. A novel pentacyclic alkaloid from marine-derived fungus Penicillium citrinum. Org Lett 2004;6:3087-9. (b) Finefield JM, Kato H, Greshock TJ, Sherman DH, Tsukamoto S, Williams RM. Biosynthetic studies of the notoamides: isotopic synthesis of 
stephacidin $A$ and incorporation into notoamide $B$ and sclerotiamide. Org Lett 2011;13:3802-5.

16. (a) Liu XW, Zhou G, Yao Z. Synthesis and antitumor activities of isoxazole-fused spiropyrrolidine oxindoles. Chin J Synth Chem 2016;24:389-92. (b) Liu XW, Yao Z, Yang J, Chen ZY, Liu XL, Zhao Z, et al. 1,3-Dipolar cycloaddition enabled isoxazole-fused spiropyrrolidine oxindoles syntheses from 3-methyl-4-nitro5-alkenyl-isoxazoles and azomethine ylides. Tetrahedron 2016; 72:1364-74.

17. Chen S, Xiao L, Chen ZY. Synthesis and antitumor activities of novel pyrimidine-fused spiropyrrolidine oxindoles. Chin J Synth Chem 2017;25:14-7.

18. Huang Y, Huang YX, Sun J, Yan CG. A [3+2] cycloaddition reaction for the synthesis of spiro [indoline-3, 3'-pyrrolidines] and evaluation of cytotoxicity towards cancer cells. New J Chem 2019; 43:8903-10.

19. Barakat A, Islam MS, Ghawas HM, Al-Majid AM, El-Senduny FF, Badria FA, et al. Substituted spirooxindole derivatives as potent anticancer agents through inhibition of phosphodiesterase 1. RSC Adv 2018;8:14335-46.

20. (a) Savai R, Pullamsetti SS, Banat GA, Weissmann N, Ghofrani HA, Grimminger $F$, et al. Targeting cancer with phosphodiesterase inhibitors. Expert Opin Investig Drugs 2010;19:117-31. (b) Lotfy G, Said MM, El Sayed H, El Sayed H, Al-Dhfyan A, Aziz YM, et al. Synthesis of new spirooxindole-pyrrolothiazole derivatives: anticancer activity and molecular docking. Bioorg Med Chem 2017; 25:1514-23.

21. Islam MS, Ghawas HM, El-Senduny FF, Al-Majid AM, Elshaier YA, Badria FA, et al. Synthesis of new thiazolopyrrolidine-(spirooxindole) tethered to 3-acylindole as anticancer agents. Bioorg Chem 2019;82:423-30.

22. Barakat A, Islam MS, Ghawas HM, Al-Majid AM, El-Senduny FF, Badria FA, et al. Design and synthesis of new substituted spirooxindoles as potential inhibitors of the MDM2-p53 interaction. Bioorg Chem 2019;86:598-608.

23. Altowyan MS, Atef S, Al-Agamy MH, Soliman SM, Ali M, Shaik MR, et al. Synthesis and characterization of a spiroindolone pyrothiazole analog via X-ray, biological, and computational studies. J Mol Struct 2019;1186:384-92.
24. Liu TT, Yue J, Chen S. Catalyst-free synthesis and anti-human leukemia cells activities of chromanone-fused pyrrolidinylspirooxindoles. Chin J Synth Chem 2019;27:451-5.

25. Kamal A, Babu KS, Vardhan MV, Hussaini SA, Mahesh R, Shaik $S P$, et al. Sulfamic acid promoted one-pot three-component synthesis and cytotoxic evaluation of spirooxindoles. Bioorg Med Chem Lett 2015;25:2199-202.

26. Costa TE, Raghavendra NM, Penido C. Natural heat shock protein 90 inhibitors in cancer and inflammation. Eur J Med Chem 2020; 189:112063.

27. Rajaraman D, Doss MA, Krishnasamy K. Synthesis, characterization and biological evaluation of 3'-benzoyl-5' (furan-2-yl)-4'-phenylspiro [indoline-3, 2'-pyrrolidin]-2-one derivatives and its molecular docking studies. Int Lett Chem Phys Astron 2018;79:17-28.

28. Yang C, Li J, Zhou R, Chen X, Gao Y, He Z. Facile synthesis of spirooxindole-pyrazolines and spirobenzofuranone-pyrazolines and their fungicidal activity. Org Biomol Chem 2015;13:4869-78.

29. Mali PR, Rao LC, Bangade VM, Shirsat PK, George SA, Meshram HM. A convenient and rapid microwave-assisted synthesis of spirooxindoles in aqueous medium and their antimicrobial activities. New J Chem 2016;40:2225-32.

30. Kathirvelan D, Haribabu J, Reddy BS, Balachandran C, Duraipandiyan V. Facile and diastereoselective synthesis of 3 , 2 '-spiropyrrolidine-oxindoles derivatives, their molecular docking and antiproliferative activities. Bioorg Med Chem 2015;25:389-99.

31. Silva BV, Ribeiro NM, Pinto AC, Vargas MD, Dias LC. Synthesis of ferrocenyl oxindole compounds with potential anticancer activity. J Brazil Chem Soc 2008;19:1244-7.

32. Natarajan A, Guo Y, Harbinski F, Fan YH, Chen H, Luus L, et al. Novel arylsulfoanilide-oxindole hybrid as an anticancer agent that inhibits translation initiation. J Med Chem 2004;47: 4979-82.

33. Sochacka J. Docking of thiopurine derivatives to human serum albumin and binding site analysis with Molegro Virtual Docker. Acta Pol Pharm 2014;71:343-9.

34. Sanders JM, Monogue ML, Jodlowski TZ, Cutrell JB. Pharmacologic treatments for coronavirus disease 2019 (COVID-19): a review. Jama 2020;323:1824-36. 